ISSN 1991- 8690

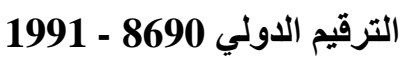

Website: http://jsci.utq.edu.iq

Email: utjsci@utq.edu.iq

\title{
Bacteriological study of diabetic foot ulcer and it's relation to metabolic control in AL-Nassriah city /Iraq
}

\author{
Basim A. Muter * Wajdi Jabbar M. * ${ }^{*} \quad$ Methaq A.Mahdi* \\ * Department of medicine - college of medicine \\ ** Department of biochemistry - college of medicine \\ Thiqar University
}

\section{Abstract:}

Background: Diabetes mellitus is a progressive disease; diabetic foot is the major complication of it, and eventually lead to development of gangrene and lower extremity amputation.

Objective: To study the relative frequency of bacterial species cultured from diabetic foot infections and it's relation to the hypoglycemic treatment

Patient and method: A case control study of 95 patients was included as two groups:

Group 1: 45 hospitalized diabetic patients in AL-Hussein teaching hospital in AL-Nassriah city with diabetic foot lesions.

Group 2 (control group): 50 diabetic patients but without diabetic foot lesions collected as outpatient from diabetic center in AL-Nassriah city.

All the 95 patients were investigated with measurement of blood sugar (RBS) and HbA1C. Deep tissue biopsies were taken from the diabetic foot lesions of the 45 patients and were inoculated into freshly prepared thioglycollate broth medium. Bacterial species were identified by conventional bacteriological methods.

Result: Clinical grading and bacteriological study of 45 patients with diabetic foot lesions revealed: Aerobic Gram-positive bacteria accounted for $71.2 \%$. Staphylococcus aureus was the most frequent (37.8\%) and Streptococci group A (20\%), and Staphylococcus epidermidis was regularly associated with the lesions (13.3\%).

Gram-negative rods accounted for (24.4\%). Pseudomonas aerogenosa was the most predominant gram negative bacilli (11.1\%), Escherichia coli (8.9\%) and Enterobacter (4.5\%), while undetected microorganism in diabetic foot ulcer was $(4.4 \%)$.

\section{Conclusions:}

Staph. aureus and Streptococcus group A were the two most common isolates detected in diabetic foot ulcer . The ages of (60-70) years were the most common age group that infected, with high percent for those with poorly controlled diabetes for long duration especially those not treated with regular insulin and poorly controlled diabetic status. 


\section{Introduction:}

Diabetes is a life threatening condition. In 2000, 3.3 million people world wide died from diabetes and it's complications (1). Diabetes is the leading cause of blindness, amputation, renal failure and cardiovascular problem (1).

These complications account for much of the social and financial burden of diabetes, although diabetes is sometimes considered to be a condition of developed nations, the loss of life from premature deaths among patients with diabetes is the greatest in developing countries (2).

Worldwide, diabetic foot lesions are a mjor medical, social and economic problem and are the leading cause of hospitalization for patients with diabetes (3).

Infectious agents are associated with amputation of the infected foot if not treated promptly .Diabetic foot lesions necessitate more hospital admissions than any other specific complication of diabetes and proper management of these infections requires appropriate antibiotic selection based on culture and antimicrobial susceptibility results (3-4).

Careful inspection of the diabetic foot on a regular basis one of the easiest, least expensive and most effective measures for preventing foot complications (4). Appropriate care of the diabetic foot requires recognition of the most common risk factors for limb loss (5) .Many of these risk factors can be identified based on specific aspects of the history and a brief but systemic examination of the foot.$(5,6)$

Diabetic foot ulcerations result from different pathophysiological mechanisms; a clear understanding of them is crucial to reduce their incidence, provide early care, and finally delay the amputation risk (6). Peripheral vascular insufficiency occurs earlier in diabetics than in non-diabetics, and the arteries of the infrapatellar segment are attacked with greater frequency. The prevalence of peripheral vascular disease is about $10 \%$ in diabetics, whereas in non-diabetics the prevalence is $2.6 \%$ (7).
Ischemia may be the cause of or contribute towards the progression of trophic lesions in the foot, which form favorable locations for infections to take hold (7).

The coexistence of neuropathy, ischemia and leukocyte immune function disorders in diabetic patients favors the development of severe and extensive infections in the lower limbs that, if not adequately treated, may lead to amputation and death (8).

Foot infections are the most common complications of diabetic foot and plays a main role in the development of moist gangrene (9).

Pseudomonas spp., Enterococcus spp.and Proteus spp. carry a special role and are responsible for continuing and extensive tissue destruction with poor blood circulation of the foot ( 10 ) .

A high frequency of anaerobic infection has also been reported (11).

The infection leads to the early development of complication even after a trivial trauma, the disease progresses and becomes refractory to antibacterial therapy (12). It is essential to assess the magnitude of bacterial infection of the lesions to avoid further complications and save the diabetic foot. Early diagnosis of microbial infections is aimed to institute the appropriate antibacterial therapy and to avoid further complications (13).

Infection with multidrug-resistant organisms may increase the duration of hospital stay and cost of management and may cause additional morbidity and mortality (14). The aim of this study was to determine the microbiological profile of organisms isolated from patients with diabetic foot ulcers.

\section{Patients and Methods:}

A case control study of 95 patients included as two groups: Group 1: 45 patients with diabetic foot lesions from medical and surgical wards of AL-Hussein teaching hospital, those patients included in this study if they had an infected ulcer, wound, osteomyelitis.Group 2 (controlled group): 50 iabetic patients but without diabetic 
foot collected as outpatients from diabetic centre in AL-Nassriah city.

All patients in this study collected from October till Augest 2011.

Data including age, gender, RBS concentration, and $\mathrm{HbA1c}$ measurement, nature of clinical specimen, and species of the isolated pathogen of the clinical isolates were recorded.

Patients were clinically assessed and the foot lesions were graded depending on the severity of lesions ( 15 ), as grade 0 : no obvious ulcer, but thick callus, prominent metatarsal heads, claw toes or any bony abnormality ; grade 1 : superficial ulcer clinically not infected ; grade 2 : deep ulcer often infected but no bone involvement ; grade 3 : deep ulcer, abscess formation and bone involvement; grade 4 : localized gangrene and grade 5 : gangrene of whole foot (16) . Grade 0 and 1 are not included in those patients because no need for admission.

Two clinical specimens including either curettage of the base of the ulcer, tissue from skin or deep wound, or needle aspiration of these abscess or bone in cases of osteomyelitis were taken from each patient with diabetic foot infection. One specimen was placed into a sterile universal bottle and the other specimen was introduced into anaerobic media (thioglycollate broth) (17).

These specimens were sent to the clinical microbiology laboratory for culture and antibiotic sensitivity testing. All specimens were Gram stained for direct examination. Pus, tissue or swab samples were processed for isolation of aerobes by inculating specimens onto the blood agar, MacConkey's agar, thioglycollate broth and Robertson's cooked meat media for aerobic and anaerobic culture at $37^{\circ} \mathrm{c}$ for two days ( 17 ) .

For the isolation of anaerobes, specimens were inoculated on blood agar plate and incubated in an anaerobic chamber at $37{ }^{\circ} \mathrm{c}$ and examined at 48 hours and 96 hours. All isolated organisms were identified by microbiological methods (17).

Three $\mathrm{ml}$ of blood samples are taken from each patient for glycohaemoglobin HbA1 - test for (fast ion - exchange Resin separation method) (18).

Whole blood is mixed with a lysing reagent containing a detergent and borate ions. Elimination of the labile Schiff's base is thus achieved during the hemolysis. The hemolysate is then mixed for 5 minutes with a weakly binding cation exchange resin. During this time, $\mathrm{HbA0}$ binds to the resin. A special resin separator is used to remove the resin from the supernatant fluid, which contains the HbA1. The glycohemoglobin percentage of total hemoglobin is determined by measuring the absorbance of the glycohemoglobin and of the total hemoglobin fraction at $415 \mathrm{~nm}$ in comparison with a standard glycohemoglobin preparation carried through the test procedure $(18,19)$.

\section{Calculation of the HbA1 content:}

Factor F determination by use of (STD):

The glycohemoglobin percentage ( $\%$ HbA1 STD) is started on the label under \%.

\section{$\mathrm{F}=($ A total $\mathrm{Hb} \mathrm{STD} \times \% \mathrm{HbA} 1 \mathrm{STD}) /(\mathrm{A}$ HbA1 STD)}

\section{Glycohemoglobin content of the sample:}

$\%$ HbA1 sample $=\mathrm{F} \times(\mathrm{A} \mathrm{HbA} 1$ sample $/ \mathrm{A}$ total $\mathrm{Hb}$ sample)

\section{Clinical interpretation:}

\begin{tabular}{|l|c|}
\hline \multicolumn{1}{|c|}{ Patients } & $\% \mathrm{HbAl}$ \\
\hline Well controlled metabolism or stabilized diabetics & $4.5 \cdot 7$ \\
\hline Diabetics, insufficiency controlled or with metabolic imbalance & $\geq 8.5$ \\
\hline
\end{tabular}

\section{Statistical Analysis:}

Data were analysed using Excel (Microsoft, Redmond, USA) while relative risk ratios and $2 \mathrm{x}$ 2 chi-square analysis was performed.

\section{Results:}

Among 45 patients with diabetic foot (group 1), 24 were males and 21 were females and the 
age ranged from 40 to 80 years mean age being 60 years .

While group 2 (control group) were 50 diabetic patients , 27 were males while 23 were females and their age ranged from 40 to 75 year .

Table 1 indicate that most of patients with diabetic foot are in the sixties (44.4\%) and fifties $(31.2 \%)$. Out of the 45 patients 24 were males $(53.3 \%), 21$ were females $(46.7 \%)$.

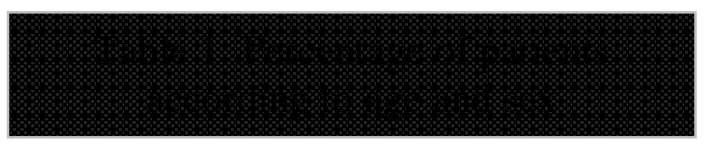

\begin{tabular}{|c|c|c|}
\hline & Group 1 & Group 2 \\
\hline $\begin{array}{c}\text { Age } \\
40-50\end{array}$ & $\begin{array}{c}5 \\
(11.1 \%)\end{array}$ & $\begin{array}{c}7 \\
(14 \%)\end{array}$ \\
\hline $\begin{array}{c}\text { Age } \\
51-60\end{array}$ & $\begin{array}{c}14 \\
(31.2 \%)\end{array}$ & $\begin{array}{c}18 \\
(36 \%)\end{array}$ \\
\hline $\begin{array}{c}\text { Age } \\
61-70\end{array}$ & $\begin{array}{c}20 \\
(44.4 \%)\end{array}$ & $\begin{array}{c}20 \\
(40 \%) \\
\end{array}$ \\
\hline $\begin{array}{c}\text { Age } \\
71-80 \\
\end{array}$ & $\begin{array}{c}6 \\
(13.3 \%) \\
\end{array}$ & $\begin{array}{c}5 \\
(10 \%) \\
\end{array}$ \\
\hline Males & $\begin{array}{c}24 \\
(53.33 \%)\end{array}$ & $\begin{array}{c}27 \\
(54 \%) \\
\end{array}$ \\
\hline Females & $\begin{array}{c}21 \\
(46.67 \%)\end{array}$ & $\begin{array}{c}23 \\
(46 \%) \\
\end{array}$ \\
\hline Total & 45 & 50 \\
\hline
\end{tabular}

Table 2 indicate that the majority of patients with diabetic foot ( number $=32,71.1 \%$ ) were being treated by oral hypoglycemic drugs , 7 patients were treated with insulin ( $15.6 \%$ ) and 6 with combination of drugs and insulin $(13.3 \%)$.

Table 2: Percentage of patients according to the type of treatment

\begin{tabular}{|c|c|c|}
\hline Type of treatment & Group 1 & Grou 2 \\
\hline Insulin & $\begin{array}{c}7 \\
(15.6 \%)\end{array}$ & $\begin{array}{c}20 \\
40 \%)\end{array}$ \\
\hline Oral hypoglycemic drug & $\begin{array}{c}32 \\
(71.1 \%)\end{array}$ & $\begin{array}{c}10 \\
20 \%)\end{array}$ \\
\hline Combination of treatment & $\begin{array}{c}6 \\
(13.3 \%)\end{array}$ & $\begin{array}{c}20 \\
40 \%)\end{array}$ \\
\hline Total & 45 & 50 \\
\hline
\end{tabular}

Table 3 indicate that the majority of the patients with diabetic foot lesions

(number $=23,51.1 \%$ ) have bad control diabetic status ( HbA1c > 8.5) .

Table 3: Percentage of patients according to the metabolic

\begin{tabular}{|c|c|c|c|}
\hline & $\begin{array}{l}\text { Control } \\
\text { group }\end{array}$ & $\begin{array}{c}\text { Case group } \\
\text { (Diabetic foot) }\end{array}$ & Total \\
\hline $\begin{array}{c}\text { Good control } \\
\text { HbAlc }<7 \\
\text { Group } 1\end{array}$ & $\begin{array}{c}27 \\
(54 \%)\end{array}$ & $\begin{array}{c}15 \\
(33.3 \%)\end{array}$ & 42 \\
\hline $\begin{array}{c}\text { Fair control } \\
\text { HbA1c: } 7-8.5 \\
\text { Group } 2\end{array}$ & $\begin{array}{c}10 \\
(20 \%)\end{array}$ & $\begin{array}{c}7 \\
(15.5 \%)\end{array}$ & 17 \\
\hline $\begin{array}{c}\text { Bad control } \\
\text { HbA1c }>8.5 \\
\text { Group } 3\end{array}$ & $\begin{array}{c}13 \\
(26 \%)\end{array}$ & $\begin{array}{c}23 \\
(51.1 \%)\end{array}$ & 36 \\
\hline Total & 50 & 45 & 95 \\
\hline
\end{tabular}

* Significant difference between the two groups ( $\mathrm{P}$ value $<0.045)$.

Table (4) indicate the frequency of occurrence of bacterial isolates from the diabetic foot ulcer.

Table 4: Percentage of bacterial isolates from patients with diabetic foot ulcer

\begin{tabular}{|c|c|}
\hline Bacterial isolates & No. (\%) \\
\hline Gram-Positive bacteria & $32(71.2 \%)$ \\
Staphylococcus aureus & $17(37.8 \%)$ \\
Staphlococcus epidemidis & $6(13.3 \%)$ \\
Group A stretococci & $9(20 \%)$ \\
& $11(24.4 \%)$ \\
\hline Gram-Negative bacteria & $4(8.9 \%)$ \\
Escherichia coli & $5(11.1 \%)$ \\
Pseudomonas aenuginosa & $2(4.5 \%)$ \\
\hline Undetebacter Spp & $2(4.4 \%)$ \\
\hline diabetic foot ulcer & \\
\hline
\end{tabular}




\section{Discussion :}

All the patients in this study were hospitalized due to the severity of their foot ulcers, which categorized into grade 3 to 5 . In the present work we found that the males were slightly more affected by diabetic foot lesions than the females, and the age of 60-70 years old was the more affected age by diabetic foot ulcer which agreed to study of FryKberg (20).

Other observation in our work suggest that the majority of patients with the diabetic foot ulcers were being treated with oral hypoglycemic drugs and this agree with the study of Lipsky (21).

Other observation in our study suggest that the majority of patients with the diabetic foot ulcers had bad control diabetic status ( HbA1c > 8.5 ) but there were no relationship between the bad control diabetic status and the type of pathogen isolated from the ulcers and this agree with Wheat et al study ( 25 ).

Staphylococcus aureus was the commonest isolate, which agreed to studies of El-Tahaway (22) and Unachukwu et al (23).

The second predominant pathogen was Streptococcus group A, and Staphylococcus epidermidis was the third isolate detected in our study, and this agrees with Nadeem (24).

The majority of diabetic foot ulcers are superficial and is frequently colonized by aerobic Gram-positive bacteria (22). The most commonly isolated bacteria from diabetic foot infections are Staph. aureus, group A Streptococcus, Staph. epidermidis, Pseudomonas aeruginosa , Escherichia coli, enterococci Spp. ( 22 ) .

One study had also reported the predominance of Staph. aureus in $50 \%$ of wound specimens (26). Aerobic and anaerobic infections in diabetic ulcers and lesions have been studied extensively and found the predominance of Pseudomonas species infection among them in other studies and this not agree with this study (13).

\section{Conclusion :}

Staph. aureus and Streptococcus group A were the two most common organisms detected in diabetic foot ulcer. The ages of 60-70 years old were the most common age group to the infection , with high percentage for those with poorly controlled diabetes for long duration especially those not treated with regular insulin .

\section{Recommendation :}

1- We recommend a strict glycemic control and follow up by serial HbA1c checking especially in older age group.

2- Wound swab should be taken for each diabetic foot ulcer to determine the type of microorganism and then definit treatment .

\section{References:}

1. John L , Culleton MD. Preventing diabetic foot complication .Post graduate medicine 1999; 1: 106.

2. National Diabetic Data Group.Diabetic care. Diabetes in America 1998; 85: 139-145.

3. Goldstein EJ, Citron DM, Nesbit CA . Diabetic foot infection: bacteriology and activity of 10 oral antimicrobial agents against bacteria isolated from consecutive cases. Diabetes Care 1996; 19: 638-641.

4. Reiber GE, Pecoraro RE, Koepsell TD. Risk factors for amputation in patients with diabetes mellitus: a case-control study. Ann Intern Med. 1992; 117: 97-105.

5. Mandell G , Bennet J , Dolin R . Cellulitis and soft tissue infection. Principles and practice of infectious diseases. $6^{\text {th }}$ Pennsylvania: Churchill Livingstone $2005 ; 2: 1046-7$.

6. Frykberg RG. Diabetic foot ulcers: pathogenesis and management .Am Fam Physician 2002; 66 : 1655-62.

7. Mueller MP, Wright J, Klein SR. Diabetes and peripheral vascular disease. Principles and practice of Vascular surgery 1994; 2: 514-22 . 
8. Slovenkai MP. Foot problems in diabetes. Med Clin North Am $1998 ; 82$ : 949-71.

9. Smith JMB, Payne JE, Berue TV. Diabetic foot lesions of skin and soft tissue infections of surgical importance. The surgeons Guide to Antimicrobial Chemotherapy 2002; $2: 18-21$.

10. Armstrong DG, Lavery LA. Diabetic Foot Ulcers : Prevention, Diagnosis and Classification . Am Farm Physician 1998;57:1325-32 .

11. Baily TS , Yu HM, Rayfield EJ. Patterns of foot examination in a diabetic clinic. Am $\mathrm{J}$ Med 1985; 78:371-4 .

12. Pittet D, Wyssa B , Herter-Clevel C, Kursteiner K , Vaucher J , Lew PD . Outcome of diabetic foot infections treated conservatively a retrospective cohort study with long term follow up . Arch Inter Med J 1999; 159 : 851-856.

13.C Anandi, D Alaguraja, V Natarajan, $M$ Ramanathan, CS Subramaniam, M Thulasiram, S Sumithra.Bacteriology of diabetic foot lesions. Indian Journal of Medical Microbiology 2004;22: 175-178.

14. Hartemann-Heurtier A, Robert $\mathbf{J}$, Jacqueminet $S$, Ha Van G, Golmard JL, Jarlier V, Grimaldi A : Diabetic foot ulcer and multidrug-resistant organisms : risk factors and impact . Diabet Med J 2004; 21:710-715.

15. Blazar K , Heidrich M . Diabetic gangrene of the foot . Chirueg 1999; 70: 831-844.

16. Wagner FW . The diabetic foot. Orthopedics 1987 ; 10:163-72 .

17. Forbes BA, Sahm DF, Weissfeld AS . Bailey and Scott's Diagnostic Microbiology. $11^{\text {th }}$ Ed. , Mosb Inc.y : St. Louis , USA, 389-97 .

18. Gorka G , Labor-Medizin . Clin Biochem 1985; 1: 30-31.

19. James T.M. et al . Clin.Biochem $1981 ; 14: 25-27$. 2o. Frykberg RG, Armstrong DG, Giurini J , Edwards A, Kravette M ,Kravitz S, et al . Diabetic foot disorders. J Foot Surg 2000 ; 39: 51-60

21. Lipsky BA, Berendt AR, Deery HG, Embil JM, Joseph WS, Karchmer AW, et al . Diagnosis and treatment of diabetic foot infections .J Am Med Assoc 2005;95:183-210 .

22. El-Tahawy AT. Bacteriology of diabetic foot. Saudi Med J 2000 ; 21:344-7 .

23. Unachukwu $\mathrm{CN}$, Obunge OK, Odia OJ. The bacteriology of diabetic foot ulcers in Port Harcourt, Nigeria. Nigr J Med 2005;14:173-6 .

24. Nadeem S Raja. Microbiology of diabetic foot infections in a teaching hospital in Malaysia : a retrospective study of 194 cases . J Microbiol Immunol Infect 2007;40:39-44 .

25. Wheat LJ, Allen SD, Henry M, Kernek CB, Siders JA, Kuebler T, et al . Diabetic foot infections. Bacteriologic analysis. Arch Intern Med J 1986; 146 :1935-40 .

26. Slater RA, Lazarovitch $T$, Boldur I, Ramot $Y$, Buchs A, Weiss $\mathrm{M}$, et al . Swab cultures accurately identify bacterial pathogens in diabetic foot wounds not involving bone. Diabet Med J 2004; 21: 704-9. 
در اسة التو اجد الجرثومي لقرحة القدم السكرية و علاقته بالسيطرة الايضية لداء السكري في الناصرية / العر اق

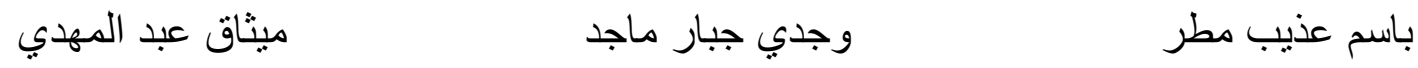

$$
\begin{aligned}
& \text { كلية الطب - جامعة ذب قار }
\end{aligned}
$$

الخلاصة: داء السكري هو مرض تقدمي , واصابات القدم السكرية قد تؤدي في النهاية الى الغنغرينا وبتر الاطراف السفلى ـ ان الهدف من

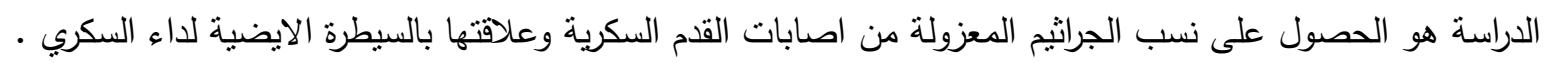

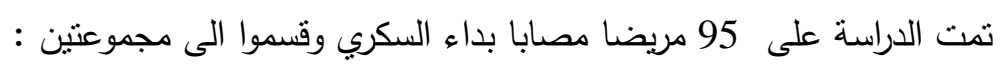
المجموعة الاولى : 45 مريضا يثكون من اصابات القدم السكرية وهم مرضى راقدون في مستشفى الحسين التعليمي في مدينة الناصرية

المجموعة الثانية : 50 مريضا مصاب بداء السكري فقط بدون اصابة القدم السكرية وهم مرضى مراجعين لمركز السكري في الناصرية .

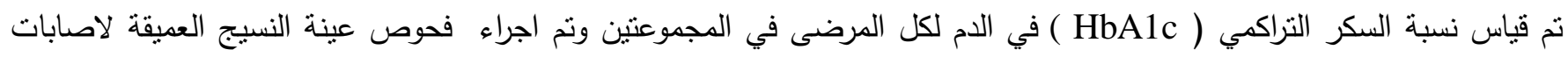

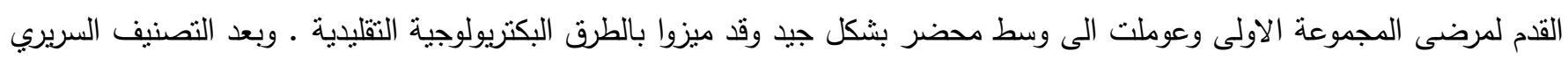

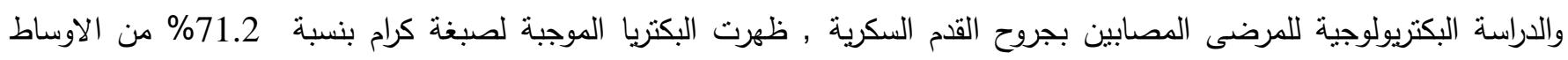

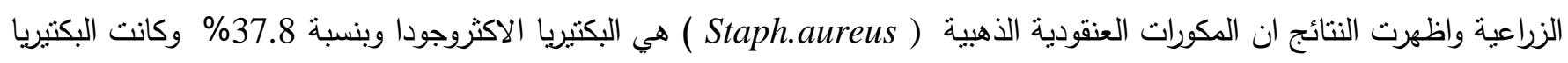

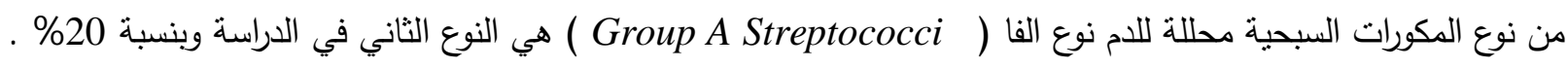

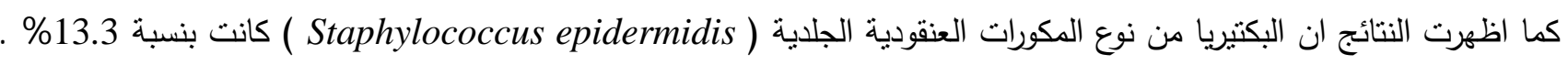

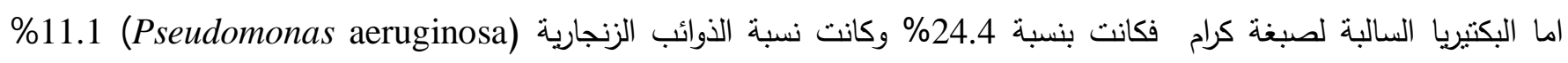

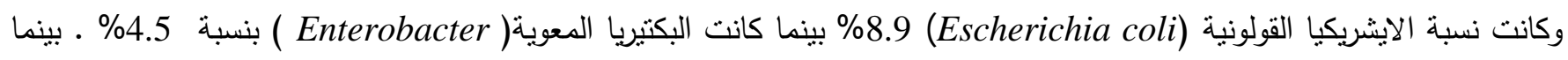

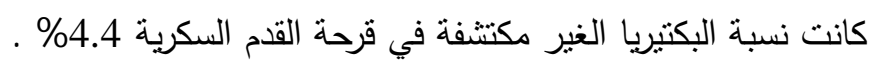

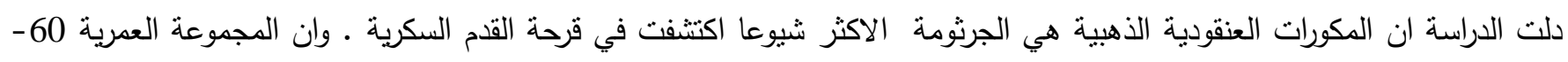

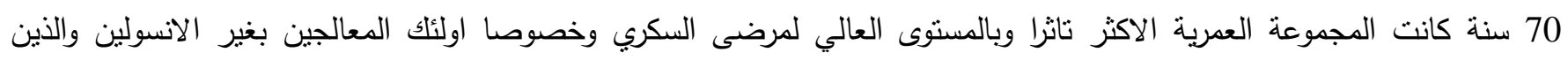

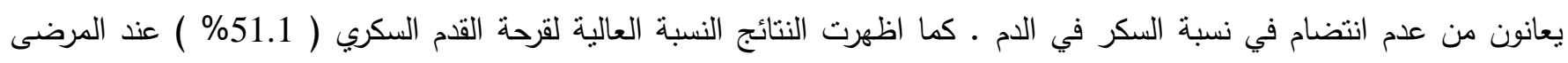

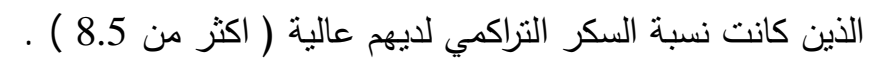

